Scientia Agricola

http://dx.doi.org/10.1590/0103-9016-2014-0056

\title{
Seasonality of soil water exchange in the soybean growing season in southern Brazil
}

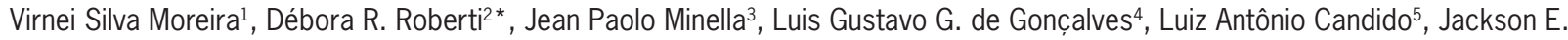
Fiorin ${ }^{6,7}$, Osvaldo L. L. Moraes², Andréa U. Timm ${ }^{8}$, Reimar Carlesso ${ }^{9}$, Gervásio Annes Degrazia²

'Federal University of Pampa, R. Luiz Joaquim de Sá Britto, $\mathrm{s} / \mathrm{n}$ - Campus Itaqui - 97650-000 - Itaqui, RS - Brazil.

${ }^{2}$ Federal University of Santa Maria/CCNE - Dept. of Physics, Av. Roraima, 1000 -97105-900 - Santa Maria, RS - Brazil.

${ }^{3}$ Federal University of Santa Maria/CCR - Dept. of Soil Science.

${ }^{4}$ Center for Weather Forecasting and Climate Research (CPTEC/INPE), Rod. Dutra, km 39 - 12630-000 - Cachoeira Paulista, SP - Brazil.

${ }^{5}$ National Institute of Amazonian Research (INPA), Av. André Araújo, 2.936 - 69067-375 - Manaus, AM - Brazil.

${ }^{6}$ Center of Experimentation and Research (CCGL TEC), RS

342-km 149 - 98.005-970 - Cruz Alta, RS - Brazil.

${ }^{7}$ Cruz Alta University, Rod. Municipal Jacob Della Méa, km

5.6 - 98020-290 - Cruz Alta, RS - Brazil.

${ }^{8}$ Faculty of Serra Gaúcha (FSG), R. Os Dezoito do Forte,

2366 - 95020-472 - Caxias do Sul, RS - Brazil.

${ }^{9}$ Federal University of Santa Maria/CCR - Dept. of Rural

Engineering.

*Corresponding author <debora@ufsm.br>

Edited by: Silvia del Carmen Imhoff

Received February 12, 2014

Accepted August 13, 2014
ABSTRACT: The processes of water transfer in the soil-plant-atmosphere system are strongly affected by soil use and management. Differences in the dynamics of soil water transfer between no-tillage (NT) and conventional tillage (CT) practices during a soybean (Glycine max) growing season in southern Brazil were assessed in this study. All the water balance components were analyzed during the soybean growing season (2009/2010). Rainfall, runoff, soil water storage and hydro-physical soil properties were analyzed under two tillage systems. The land-atmosphere water vapor exchanges, obtained from eddy covariance stations, were analyzed with regard to the soybean agroecosystem. Characterizations of soil water storage were also formulated in the 2006/2007 and 2008/2009 soybean growing seasons under the NT system. During the periods without rain, the soil water content under NT was greater than under CT. The soil superficial layer, more porous under NT, contributed to less runoff during rainy events. Moreover, under NT conditions the water supply was always high, between $0.2-0.5 \mathrm{~m}$. The total evapotranspiration in the soybean agroecosystem growing season was $410.8 \mathrm{~mm}$.

Keywords: water balance, soil water content, evapotranspiration, no-tillage, conventional tillage

\section{Introduction}

Southern Brazil is known for being a major grain producer. Crop cultivation began in the early 1960s under conventional tillage (CT). By the 1990s, most of the crops had adopted the no-tillage (NT) system. A better understanding of the differences between the two management systems should help to improve our understanding of the interaction between the land surface and the atmosphere (Lokupitiya et al., 2009; Kucharik and Twine, 2007).

Water exchanges in the soil-plant-atmosphere system are largely controlled by soil hydro-physical characteristics, which are exceptionally variable in space and very sensitive to soil management and use (Kay and Bygaart, 2002). Conventional cultivation practices involving intense soil disturbance usually result in low bulk density in the upper soil layers, with less aggregation and high permeability although compression of the subsurface layer due to the use of machinery can also be found (Reichert et al., 2009). Nonetheless, tillage could also compact the top layer due to the use of heavier machinery and a lower frequency of soil disturbance. This can lead to higher density in the surface layer, and reduce water infiltration in the soil (Reichert et al., 2009; Botta et al., 2010).
Changes in soil structure that are induced by both NT and CT cultivation practices generate significant differences in aggregation, bulk density, and pore discontinuity and directly affect the water balance components of the system, such as runoff, soil water content, and evapotranspiration (ET). This study focuses on the state of Rio Grande do Sul (RS), Brazil, where water deficit is one of the main limiting factors affecting soybean yields (Matzenauer et al., 1998; Mota et al., 1996). The water deficit can also cause physiological changes in the soybean including premature loss of flowers and leaves and reductions in grain productivity (Dogan et al., 2007; Egli and Bruening, 2004).

This study aims to quantify the magnitude and seasonal distribution of the water balance components for soybean crops under NT and CT in southern Brazil. Additionally, an analysis of hydro-physical soil characteristics due to different soil management practices and the seasonal variation of the crop coefficient (Kc) for the soybean agroecosystem were carried out.

\section{Materials and Methods}

Site description and cultural practices

The area of study was in Cruz Alta (RS) (-28 $36^{\prime}$,- 
$\left.53^{\circ} 40^{\prime}, 425 \mathrm{~m}\right)$. The climate is Cfa (Köppen) subtropical humid, with climatic average annual rainfall of 1,755 $\mathrm{mm}$ evenly distributed throughout the year, and the minimum in Nov (120 mm), and maximum in Oct (186 $\mathrm{mm})$. The average annual daily temperature is $18.7^{\circ} \mathrm{C}$, with average minimum daily temperatures of $8.6^{\circ} \mathrm{C}$ in Jul (Austral Winter) and an average maximum of 30.0 ${ }^{\circ} \mathrm{C}$ in Jan (Austral Summer). These averages (rainfall and temperature) were obtained using the precipitation data measured at the meteorological station of INMET (Instituto Nacional de Meteorologia) located in the same research center.

The native vegetation is Araucaria open forest and natural rangeland formed by grasses, predominantly Paspalum notatum Fluegge. After the 1950s, the area has been deforested and converted into commercial agricultural land, where wheat (Triticum aestivum L.) / soybean (Glycine max L.) have been planted successively using CT. In 1985, an experimental setup was installed in order to compare NT with CT consisting of an array of $40 \mathrm{~m} \times 60 \mathrm{~m}$ plots arranged in pairs. Experiments with crops are conducted in each pair of plots, one under an NT system, the other under a CT system (Figure 1). A great variety of measurements in soil and atmosphere has been observed over several years, and these measurements have been used to support different studies (Amado et al., 2006; Chavez et al., 2009; Fabrizzi et al., 2009; Boddey et al., 2010; Escobar et al., 2010).

The soil data used in this paper were collected in plots under CT and NT systems with the following 3-year rotation: Year 1, common vetch (Vicia sativa L.) mixed with black oat (Avena strigosa L.) in winter and maize (Zea mays L.) in summer; Year 2, wheat in winter and soybean in summer; and Year 3, black oat in winter and soybean in summer. The soybean in the last period (Year 3) was also grown in the surrounding region.

Soil water storage was characterized in three soybeans growing season: (2006/2007), (2008/2009) and (2009/2010) for the NT system. The differences in soil water transfer dynamics between no-tillage (NT) and conventional tillage $(\mathrm{CT})$ practices were studied during the soybean growing season for 2009/2010 commencing 14 Dec 2009 (sowing). On 13 Apr, physiological maturity was identified and the crop harvested on 28 Apr 2010. Usually the planting of soybeans in this region occurs in Nov, but due to excessive rainfall during Nov of that year the sowing was delayed. After physiological maturity, there was also a large amount of rainfall, for two weeks, which also delayed the harvest. Weed control was conducted approximately 25 and 40 days after sowing. Fertilization and other cultural treatments were applied according to the technical recommendations.

The soil at the experimental site is Rhodic Ferralsol (FAO Soil Taxonomy) or Typic Haplorthox (US Soil Taxonomy), clayey and deep, with a $1 \%$ slope. At a depth of 0-0.2 $\mathrm{m}$, this soil has the following characteristics: clay $=520 \mathrm{~g} \mathrm{~kg}^{-1}$, silt $=240 \mathrm{~g} \mathrm{~kg}^{-1}$, sand $240 \mathrm{~g} \mathrm{~kg}^{-1}$, organic matter ${ }_{\text {(Walkley-Black) }}=32 \mathrm{~g} \mathrm{~kg}^{-1}, \mathrm{pH}_{(\mathrm{H} 2 \mathrm{O})}=5.5, \mathrm{P}_{(\text {Mehlich-1) }}=17$ $\mathrm{mg} \mathrm{kg}^{-1}, \mathrm{~K}_{(\text {Mehlich-1) }}=3.8 \mathrm{mmol}_{\mathrm{c}} \mathrm{kg}^{-1}, \mathrm{Al}$ exchangeable ${ }_{(1 \mathrm{M}}$ KCl) $=2.0 \mathrm{mmol}_{\mathrm{c}} \mathrm{kg}^{-1}$, and $\mathrm{Ca}+\mathrm{Mg}$ exchangeable ${ }_{(1 \mathrm{M} \mathrm{KCl})}=$ $66.0 \mathrm{mmol}_{\mathrm{c}} \mathrm{kg}^{-1}$.

\section{Measurements}

\section{Soil hydrology and hydro-physical characteristics}

Runoff measurements were completed using eight galvanized steel structures, installed in the experimental area (four in each planting system). These structures were designed and arranged on the ground in order to obtain a representative mean surface flow over the study area. The structures, with dimensions of $1 \mathrm{~m}^{2} \times 15 \mathrm{~cm}$, were buried in the ground to a depth of $7.5 \mathrm{~cm}$ and fitted with a water collector system, at the lower end. After each rainy day the containers were collected and water losses computed

The soil water content $\left(\theta, \mathrm{m}^{3} \mathrm{~m}^{-3}\right)$ was estimated by a Time Domain Reflectometry (TDR) sensor sweeping the scale from 0 to $1 \mathrm{~m}^{3} \mathrm{~m}^{-3}$. The sensor consists of two rods of length $0.3 \mathrm{~m}$ in stainless steel, connected to the system for data acquisition and storage. $\theta$ was measured in the layer at a soil depth range of $0-0.05 \mathrm{~m}$ in the $(2006 / 2007)$ and (2008/2009) soybean growing seasons. In the $(2009 / 2010)$ soybean growing season, the $\theta$ was measured at two soil layer depths. The rods were inserted from the surface to a depth of $0.2 \mathrm{~m}$, and 0.2 to $0.5 \mathrm{~m}$ deep at an angle that allows for monitoring the entire soil layer. These layers were chosen because the soybean rooting system is typically distributed within a depth of. $2 \mathrm{~m}$ whereas the pivot root often reaches depths greater than $0.5 \mathrm{~m}$ (Tesar, 1984).

The sensors were installed near a micrometeorological tower within the soybean plots. In each plot, the first sensor was placed at an angle of $5^{\circ}$ to the surface to determine the volume of water in the first $0.2 \mathrm{~m}$ of soil. The second was inserted vertically into the soil to a depth of up to $0.5 \mathrm{~m}$ in order to integrate the total water volume from $0.20 \mathrm{~m}$ to $0.5 \mathrm{~m}$. Soil drainage was calculated by measuring the water excess between 0.2 and $0.5 \mathrm{~m}$ (Darcy's Law). The measurements were initiated on 19 Dec 2009, five days after planting, and continued until the end of the experiment on 28 Apr 2010.

One trench was opened in each experimental plot, 15 days before the soil ploughing $(\mathrm{CT})$ or seeding $(\mathrm{NT})$, where three samples were collected at each soil depth: $0.05,0.12,0.30$, and $0.60 \mathrm{~m}$. Soil samples were collected from non-preserved soil structure to permit the determination of texture, particle density and soil water retention curve (SWC) and samples with preserved soil structure were collected with $5-\mathrm{cm}$ high metal rings with a $6.05-\mathrm{cm}$ diameter to determine the saturated soil hydraulic conductivity $\left(\mathrm{K}_{\theta \mathrm{s}}\right)$, bulk density $(\rho \mathrm{b})$, and SWC with (Richards chamber).

Total porosity (TP) was determined using SWC. Macroporosity (Mac) was calculated by the difference between TP and water content $(\theta)$ at $6 \mathrm{kPa}$ tension. Microporosity (MIC) was estimated by the difference be- 


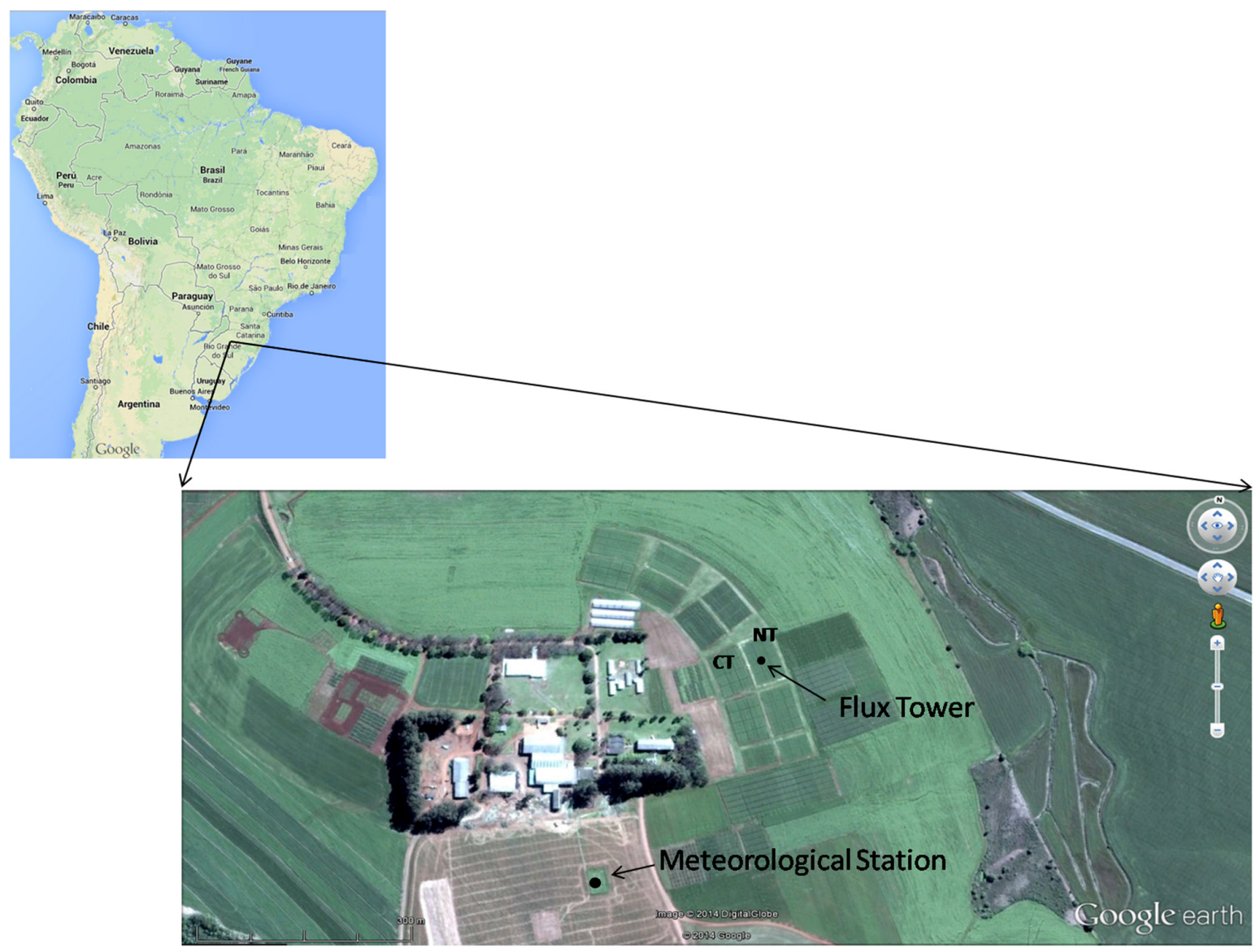

Figure 1 - Cruz Alta experiment site located in southern South America. The location of NT and CT plot, the flux tower and the meteorological station are represented. The figure was not obtained during the period of the experiment analyzed in this study.

tween TP and Mac. The permanent wilting point (WP) and field capacity (FC) were estimated using $\theta$ at 1500 and $10 \mathrm{kPa}$ tension, respectively. The available soil water capacity (AWC) was calculated as the difference between field capacity (FC) and the wilting point (WP). The $\mathrm{K}_{\theta \mathrm{s}}$ was determined using a falling head permeameter $(\mathrm{Gu}-$ biani et al., 2010). To check the statistical significance to $\mathrm{K}_{\theta \mathrm{s}^{\prime}}$ we applied a $\mathrm{T}$ test with paired samples at the same depth.

\section{Radiation and turbulent fluxes}

An eddy covariance tower was installed in the center of the NT system plot. The tower comprised sensors that conduct the following measures at $10 \mathrm{~Hz}$ (sensor height above ground on the tower, manufacturer, model): wind component and air temperature $(2.5 \mathrm{~m}) ; \mathrm{H}_{2} \mathrm{O} /$ $\mathrm{CO}_{2}$ gas analyzer and pressure; incoming shortwave radiation $(5 \mathrm{~m})$; net radiation $(5 \mathrm{~m}$; incoming photosynthetically active radiation (PAR) $(1 \mathrm{~m})$; soil heat flux $(-2$ $\mathrm{cm})$; precipitation $(1.5 \mathrm{~m})$; soil temperature $(-2 \mathrm{~cm})$.

During the period of this study, the region around the soil experiment was cultivated with soybean. The fetch of the eddy covariance tower is more than $100 \mathrm{~m}$ to the west and southwest and more than $200 \mathrm{~m}$ in the other direction, with the wind direction prevailing from the southeast. Approximately $400 \mathrm{~m}$ from the eddy covariance tower, there was a meteorological station, which had been measuring the atmospheric driving forces since 1974, being the climate variables described in this study, obtained at this station.

\section{Eddy covariance data processing, gap-filling and evapotranspiration}

Turbulent fluxes were corrected for inadequate sensor frequency response following standard methods in addition to de-spiking, coordinate rotation, and air density corrections (Webb et al., 1980; Baldocchi et al., 1988; Wyngaard, 1990; Aubinet et al., 2000).

Latent heat fluxes (LE), sensible heat flux $(\mathrm{H})$ and soil heat flux $(\mathrm{Fg})$ were estimated over 30min intervals, and periods with physically inconsistent values (i.e. LE $<-50 \mathrm{~W} \mathrm{~m}^{-2}$ or $>1000 \mathrm{~W} \mathrm{~m}^{-2}$ ) were discarded. This quality control procedure left a total time gap in the data of around $27 \%$ with respect to the entire period. The low gap percentage values, when compared to other eddy covariance measurements (Alberto et al., 2011) 
demonstrate the relatively high quality of the data collected and, the largest continuous gap did not exceed two days of raw data.

The gap filling applied to the turbulent fluxes was performed in two steps: (i) in the case of up to $2 \mathrm{~h}$ gaps, missing data were filled using a simple interpolation method; (ii) for gaps larger than two hours and less than four days, the method of the mean diurnal variation MDV (Falge et al., 2001) was applied. The MDV method consists of filling the gaps in a particular time period by by taking the average of seven consecutive days for the same time period

The half-hourly energy balance closure, defined as the slope of the linear fit between net radiation $(\mathrm{Rn})$ and the energy budget components $(\mathrm{H}, \mathrm{LE}, \mathrm{Fg})$ was 0.86 , representing an energy imbalance of less than $15 \%$. Several researchers have indicated a surface imbalance ranging from about $10-30 \%$, typically related to an underestimation of surface energy fluxes measured by the eddycovariance technique at a single measurement point (Aubinet et al., 2000; Wilson et al., 2002).

The Bowen ratio (H/LE) was used to close the energy balance and created the correct values of LE to generate the experimental ET (Hernandez-Ramirez et al., 2010). The daily average of LE corrected, in units of $\mathrm{W} \mathrm{m}{ }^{-2}$, is transformed into ET, in units of $\mathrm{mm} \mathrm{d}^{-1}$, by multiplying by a factor of 0.0353 . Daily ET values were summed to generate seasonal values.

The eddy covariance measurements represent the soybean agroecosystem because we do not filter these data used in the footprint from the soybean NT and CT parcels. The footprint filter was used when the data come from outside the soybean border. Therefore, we will use the same ET representing the NT and CT.

Due to the amount of rainfall during the last week of the monitoring period, the water balance components were analyzed into two periods as follows: P1 - full period (19 Dec 2009 to 25 Apr 2010), P2 - from emergence to physiological maturity (19 Dec 2009 to 19 Apr 2010) but excluding the period of intense rainfall towards the end of the monitoring. The separation into two periods, allowed for the assessment of the water balance under two distinct circumstances.

The reference evapotranspiration, ETo, was estimated using FAO's Penman-Monteith equation (Allen et al., 1998). ETo determines the rate of evapotranspiration from a reference surface, completely covered with the standard culture (bahiagrass), and provides a model of ET for different periods throughout the year.

\section{Results and Discussion}

\section{Environmental conditions}

The mean daily values of the global solar radiation $(\mathrm{Rg})$, air temperature $(\mathrm{T})$, relative humidity $(\mathrm{RH})$ and vapor pressure deficit (VPD), shown in Figure 2 (A, B, C, D), were computed for the period between soybean emergence and harvest (19 Dec 2009 to 25 Apr 2010).
The daily average of the global solar radiation was about $236 \mathrm{~W} \mathrm{~m}^{-2}$, reaching a maximum value around $400 \mathrm{~W}$ $\mathrm{m}^{-2}$, close to the Southern Hemisphere Summer solstice (23 Dec). The average daily temperature ranged between 14.5 and $28.5{ }^{\circ} \mathrm{C}$ with a mean over the entire period of $22.8^{\circ} \mathrm{C}$, a value slightly above the historical mean of $21.9{ }^{\circ} \mathrm{C}$. The daily average relative humidity ranged between $54 \%$ and $96 \%$, with a mean over the entire period of $77 \%$. The vapor pressure deficit showed a mean value over the same period of $0.63 \mathrm{kPa}$.

\section{Hydro-physical soil characteristics}

All samples taken considered the soil profile as a single layer (0 to $0.60 \mathrm{~m}$ depth). Considering all samples from the soil profile as repetitions, the probability that treatments (NT and $\mathrm{CT}$ ) are distinct to $\rho \mathrm{b}, \mathrm{TP}, \mathrm{Mac}$ and AWC is 91, 96, 98 and $94 \%$, respectively (Table 1). The values of MIC, FC and WP were not different $(p<0.05)$ between the two systems. The total porosity was greater under NT at the surface layer, attributable to its high microporosity. The $\rho b$ on the surface $(0.05 \mathrm{~m})$ was equal under both systems, possibly influenced by soil biological activity, activities of roots, and greater presence of organic matter (Périé and Ouimet, 2008; Boddey et al., 2010).

At depths greater than $0.05 \mathrm{~m}$ the NT system presents pb values on average $4 \%$ higher than under CT. The macroporosity had no difference between the systems on the surface, but for depths below $0.05 \mathrm{~m}$, CT showed the highest values. The microporosity showed an opposite pattern, with higher values under the NT system in the surface layer, but no difference in other layers. These results are reflected in the values of field capacity and wilting point, determined by the water retention curve. The difference between them defines the plant available water, which, for this site, shows a greater amount of available water under the NT system only on the surface. In lower layers, there were no differences $p<$ 0.05 ) between the two systems.

The hydraulic conductivity in saturated soil $\left(\mathrm{K}_{\theta \mathrm{s}}\right)$ had great variability for the depths (Table 2), but the CT system showed higher conductivity at all depths. Although the $\mathrm{K}_{\theta \mathrm{s}}$ may not be the most representative method to estimate infiltration in the field, it was used to indicate the differences in the soil physical-hydro conditions between the treatments which could demonstrate the impact of soil management on the soil system. The higher value of $\mathrm{K}_{\theta \mathrm{s}}$ in CT could be related to soil disturbance due to the plough that increases the Mac which, in turn, increases the $\mathrm{K}_{\theta \mathrm{s}}$ in a short time. Moreover, in some cases, there is soil compaction on the soil surface of the NT that increases the MIC.

$\mathrm{K}_{\theta \mathrm{s}}$ was also estimated for the soil profile from $0-0.3 \mathrm{~m}$ and $0.3-0.6 \mathrm{~m}$. The result, considering all samples from the soil profile $10.05 \mathrm{~m}, 0.12 \mathrm{~m}, 0.30 \mathrm{~m}$ and $0.60 \mathrm{~m})$, indicates that the probability that the samples of the two treatments have the same population is 2.36 $\%$, with mean values differing between the treatments 

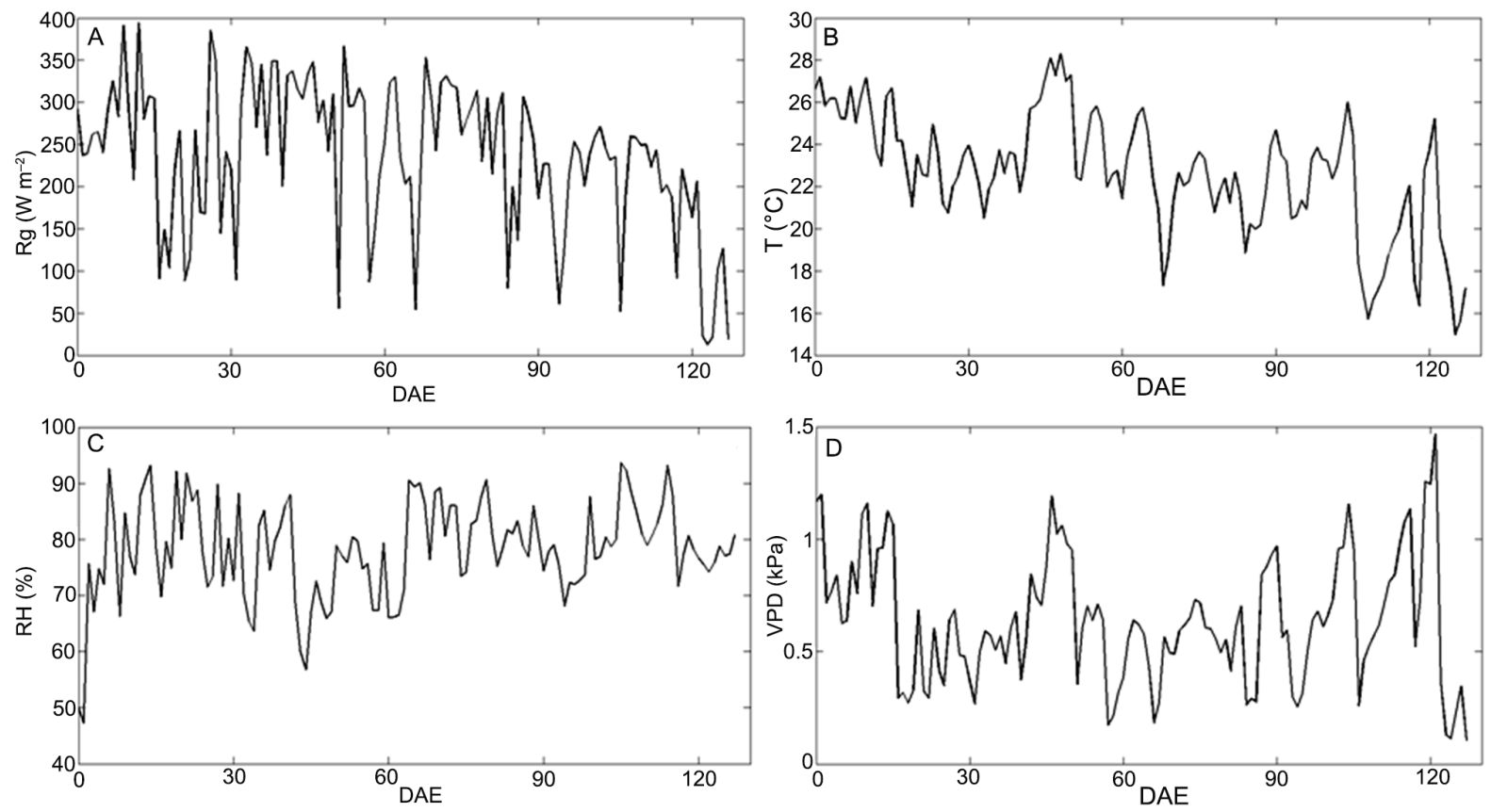

Figure 2 - Environmental conditions during the 2009/2010 soybean growing season the site of Cruz Alta. A) Global Radiation (Rg); B) Temperature (T); C) Relative Humidity (RH); D) Vapor Pressure Deficit (VPD). Timescale: Days After Emergence (DAE).

Table 1 - Hydro-physical characteristics of the soils under No Till (NT) and Conventional Tillage (CT) at different depths, obtained in the (2009/2010) soybean growing season.

\begin{tabular}{|c|c|c|c|c|c|c|c|c|}
\hline \multirow{2}{*}{ Depth $(\mathrm{m})$} & \multicolumn{2}{|l|}{$\left(\rho_{\mathrm{b}}\right)^{*}$} & \multicolumn{2}{|l|}{$(\mathrm{P})^{* *}$} & \multirow{2}{*}{$\begin{array}{c}(\mathrm{Mac})^{* *} \\
\text { CT }\end{array}$} & \multicolumn{3}{|c|}{$(\mathrm{MIC})^{\mathrm{n}}$} \\
\hline & CT & NT & CT & NT & & NT & CT & NT \\
\hline$\overline{0.05}$ & 1.34 & 1.34 & 0.48 & 0.62 & 0.12 & 0.12 & 0.36 & 0.51 \\
\hline 0.12 & 1.28 & 1.35 & 0.49 & 0.45 & 0.13 & 0.09 & 0.36 & 0.36 \\
\hline 0.30 & 1.24 & 1.30 & 0.48 & 0.46 & 0.10 & 0.08 & 0.38 & 0.38 \\
\hline 0.60 & 1.13 & 1.19 & 0.53 & 0.49 & 0.14 & 0.11 & 0.39 & 0.39 \\
\hline \multirow[t]{2}{*}{ Depth (m) } & $(\mathrm{FC})^{n}$ & & $(W P)^{n}$ & & $(A W C)^{*}$ & & $\left(K_{\theta s}\right)^{* *}$ & \\
\hline & CT & NT & CT & NT & CT & NT & CT & NT \\
\hline$\overline{0.05}$ & 34 & 49 & 18 & 17 & 16 & 32 & 409 & 1 \\
\hline 0.12 & 34 & 34 & 17 & 17 & 17 & 17 & 34 & 17 \\
\hline 0.30 & 36 & 36 & 20 & 19 & 16 & 17 & 164 & 13 \\
\hline 0.60 & 36 & 36 & 22 & 21 & 14 & 16 & 20 & 7 \\
\hline
\end{tabular}

${ }^{*} p>90 \% ;{ }^{* *} p>95 \%, n p<90 \%$.

Soil bulk density $\left(\rho_{\mathrm{b}}\right)\left(\mathrm{g} \mathrm{cm}^{-3}\right)$, total porosity (P) $\left(\mathrm{cm}^{3} \mathrm{~cm}^{-3}\right)$, Macroporosity (Mac) $\left(\mathrm{cm}^{3} \mathrm{~cm}^{-3}\right)$, microporosity (MIC) $\left(\mathrm{cm}^{3} \mathrm{~cm}^{-3}\right)$, field capacity (FC) (\%), wilting point (WP) $(\%)$, available water capacity (AWC) (\%), saturated hydraulic conductivity in soil $\left(\mathrm{K}_{\theta \mathrm{S}}\right)\left(\mathrm{mm} \mathrm{h}^{-1}\right)$.

$(p<0.05)$. The $\mathrm{K}_{\theta \mathrm{s}}$ presented the same behavior as those obtained for specific depths, which meant that, $\mathrm{K}_{\theta \mathrm{s}}$ is greater for CT and the average for the $\mathrm{K}_{\theta \mathrm{s}}$ integrated profile of 0-0.60 $\mathrm{m}$ was $135 \mathrm{~mm} \mathrm{~h}^{-1}$ for CT and $9.91 \mathrm{~mm} \mathrm{~h}^{-1}$ for the NT, with coefficients of variation of $121 \%$ and $102 \%$ respectively (Table 2 ).

These results may imply that in areas under the NT system, the infiltration rate is reduced dramatically when the soil is saturated, which might generate greater runoff. Consequently, storage of soil water can be reduced because there is a restriction on water infiltration into the soil. However, $\mathrm{K}_{\theta \mathrm{s}}$ resembles water infiltration into the soil at the basic infiltration velocity in a condition of saturated soil.

Various factors can influence the spatial and temporal soil physical characteristics such as geochemical processes or erosion. For instance, Kay and Bygaart (2002) studied the changes in soil physical properties due to variations in vegetation cover. Thus, comparisons between soil management practices need care, and differences due to soil heterogeneity and long term management practices should be considered. In the experi- 
ment presented here, the plots have the same history of land use and are only $10 \mathrm{~m}$ apart in order to ensure soil homogeneity. Thus, the differences found in the experiment are due primarily to soil management.

\section{Precipitation and runoff}

Accumulated total precipitation was $654.8 \mathrm{~mm}$ and accumulated total runoff was 12.1 and $20.6 \mathrm{~mm}$ for NT and CT, respectively (Figure 3). Runoff represents a small contribution to the water budget. Nevertheless, major losses by runoff were recorded at the beginning of the soybean cycle (Figure 3B). The differences in initial surface conditions between the two plots resulted in different infiltration into the soil as CT showed higher runoff than NT.

Despite the higher $\mathrm{K}_{\theta \mathrm{s}}$ in $\mathrm{CT}$ increasing the infiltration, there is a possibility that, after rainfall, a for-

Table 2 - Saturated hydraulic conductivity $\left(\mathrm{K}_{\theta \mathrm{S}}\right)$ integrated for different depths in No Till (NT) and Conventional Tillage (CT), obtained in the (2009/2010) soybean growing season.

\begin{tabular}{|c|c|c|c|}
\hline Depth (m) & $\begin{array}{l}\left(\mathrm{K}_{\theta \mathrm{S}}\right)(\mathrm{mm} \\
\mathrm{CT}\end{array}$ & NT & $\mathrm{T}$ test \\
\hline $0-0.30$ & $176.41(110 \%)$ & $3.11(104 \%)$ & 0.101 \\
\hline $0.30-0.60$ & 94.97 (141%) & $8.80(108 \%)$ & 0.155 \\
\hline $0-0.60$ & 135.69 (121 \%) & $9.91(102 \%)$ & 0.023 \\
\hline
\end{tabular}
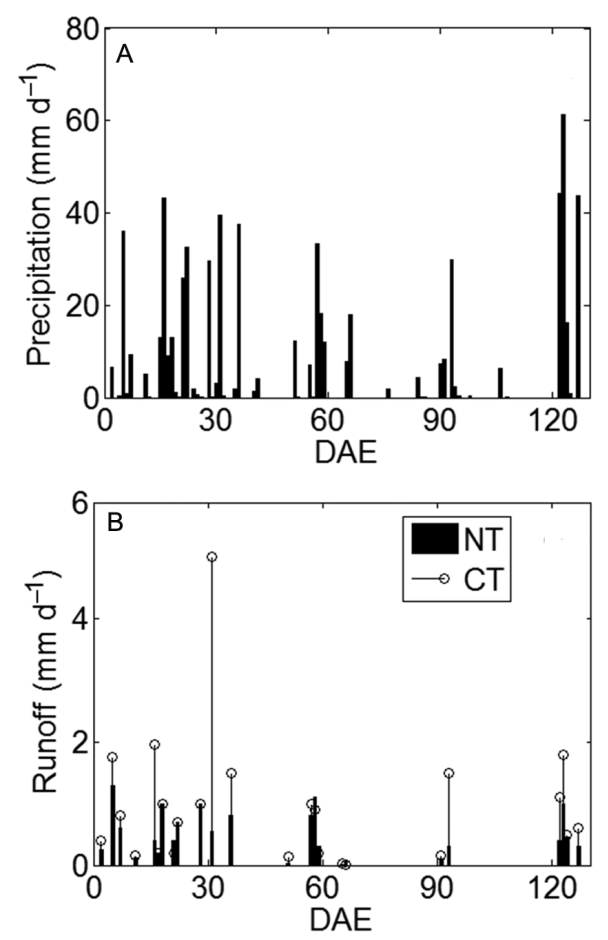

Figure 3 - Seasonal distributions of (A) precipitation and (B) runoff for systems No Till (NT) and Conventional Tillage (CT), during the 2009/2010 soybean growing season at the site of Cruz Alta. mation of surface sealing increased the runoff basically due to the reduction of infiltration rates under the CT system. Furthermore, under NT, even with less $\mathrm{K}_{\theta \mathrm{s}^{\prime}}$ there is a greater amount of cover residue on the surface that intercepts the rain and increases flow resistance and thereby increases infiltration and reduces the runoff. As the plants grow, in the following months, the two plots converge to similar runoff losses.

Water losses by runoff during the rainfall events were higher under CT representing $83 \%$ of runoff events whereas NT had a higher runoff in only $16 \%$ of the events. NT had reduced runoff due to the increased soil cover (Engel et al., 2009; Leys et al., 2010; Tan et al., 2002). In some rainfall events, NT showed higher rates of runoff in comparison with $\mathrm{CT}_{\text {; }}$ in general it happened after relatively long precipitation periods suggesting that the NT soil was near saturation. Even though the Mac is higher under $\mathrm{CT}$, formation surface sealing may occur, increasing the runoff in this system. Under NT the largest mulch increases the friction of flow and promotes infiltration. However, for the larger rainfall events, the NT system can generate high rates of runoff, because the lower values of Mac decrease the infiltration rates.

\section{Soil water content}

In the top soil layer $(0-0.20 \mathrm{~m}) \mathrm{CT}$ reached higher values during the wet period and lower values during the dry period, when compared to NT (Figure 4). The wet period occurred from 0 to 60 DAE whereas the dry period began after 60 DAE. These differences were mainly due to CT's higher hydraulic conductivity, which favored higher infiltration rates into the soil surface. The highest value of Mac in CT represents higher gases and heat transfer, with higher temperature range and water loss by evaporation. In the second layer (between $0.2 \mathrm{~m}$ to $0.5 \mathrm{~m}$ depths) NT water content was always higher than $\mathrm{CT}$, even with a low $\mathrm{K}_{\theta \mathrm{s}}$ value. In $\mathrm{NT}$ there is no surface sealing and the straw increases the infiltration and, therefore, increases AWC in the deeper layers.

Integration of the soil water content at depths of 0-0.5 $\mathrm{m}$ shows that during the wet period, when the rate of precipitation is at its highest, the two systems had the same soil water content (see Figure 4C, from 5 to 50 DAE). During the period of greatest reduction in water content, the dry period, NT had a higher soil water content compared to $\mathrm{CT}$, recording $17 \mathrm{~mm}$ of more humidity than CT around 120 DAE. During the period of study, the soil water content in both systems never reached the WP values.

Although the time series of soil water content analyzed above is relatively short, it covers a broad range of soil moisture conditions. We used two additional soybean growing seasons of soil moisture data (2006/2007 and 2008/2009) to verify the variation of soil moisture sensors and efficiency in explaining the pattern of soil water content in the CT. Considering the total porosity of $0.48 \mathrm{~cm}^{3} \mathrm{~cm}^{-3}$ (Table 1) for a layer of $5 \mathrm{~cm}$ of soil, the 

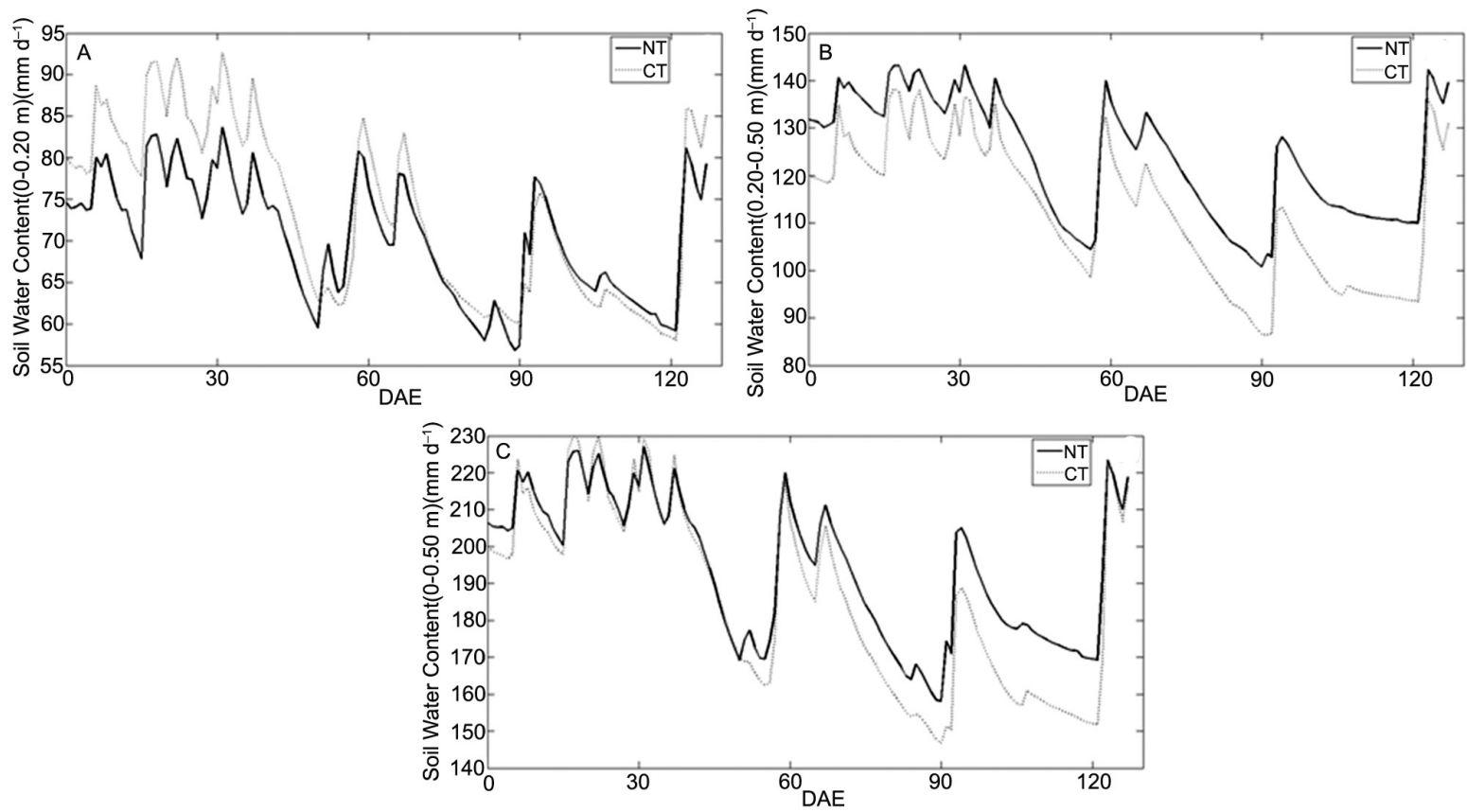

Figure 4 - Variation of soil moisture for the 2009/2010 soybean growing season in No Till (NT) and Conventional Tillage (CT) at depths A) (0$0.2 \mathrm{~m})$, B) $(0.2-0.5 \mathrm{~m})$, C) $(0-0.5 \mathrm{~m})$.

FC and WP are, respectively, 0.34 and $0.18 \mathrm{~cm}^{3} \mathrm{~cm}^{-3}$, this corresponds to a layer of $17 \mathrm{~mm}$ and $9 \mathrm{~mm}$ of water in the soil (Figure 5). For the 2008/2009 season, soil water content values ranged between field capacity and wilting point, although, at the end of the growing season the soil moisture was below the wilting point (Figure 5). In the 2007/2008 season the soil moisture values were higher, though still within the expected margin, and the soil was largely above field capacity, near saturation.

Precipitation is a strong controlling element of variability between growing seasons, i.e., for periods with precipitation excess (2006-2007, total precipitation in soybean growing season was $728 \mathrm{~mm}$ ) soil water content varies at intervals between FC and saturation, and periods of low rainfall (2008-2009, total precipitation in the soybean growing season was $389 \mathrm{~mm}$ ) soil water content remained between field capacity and wilting point and values below that.

Considering the three monitoring cycles, $2006 / 2007,2008 / 2009$ and 2009/2010 the behavior of soil water content data from precipitation shows a reasonable standard response, which allows for an increase in the degree of confidence in the NT and CT data obtained for the different layers to complete the cycle of monitoring conducted from 2009/2010 onward.

Several authors have addressed the greater soil water storage and lower runoff in NT for different crops (Blevins et al., 1990; De Vita et al., 2007; Almaraz et al., 2009; Stipesevic and Kladivko 2005; Verkler et al., 2008). Tormena et al. (2002) and Klein and Libardi (2002) identified properties that increase water storage under NT when compared with CT for different soils and crops. Verkler et al. (2008) conducted experiments on soybean crop using both NT and CT systems, recording soil water content values over a two year period (2005 and 2006) to a depth of $0.075 \mathrm{~m}$ in the delta of the Mississippi River, in the United States. Despite little difference in soil water storage between the two tillage systems in this layer, the soil dries slower under NT and continues with higher water content, allowing for water to be available for longer periods of time.

\section{Evapotranspiration}

The seasonal pattern of daily ET for soybean shows that the major values found at the end of the vegetative phenological stage (50-60 DAE), reached almost $6 \mathrm{~mm}$ $\mathrm{d}^{-1}$ (Figure 6A). In the central region of the USA, using the eddy covariance method in rainfed soybean between 2002 and 2006, the peak of daily evapotranspiration ranged from 4.9 to $5.8 \mathrm{~mm} \mathrm{~d}^{-1}$, and the ET integrated over the soybean growing season was from 431 to 452 $\mathrm{mm}$ (Suyker and Verma, 2009; 2010). From the measurements taken in this study, ET integrated was $410.8 \mathrm{~mm}$ and the soybean average ET from emergence to harvest (entire cycle) was $3.20 \mathrm{~mm} \mathrm{~d}^{-1}$.

During soybean growth, ET is controlled mainly by local atmospheric conditions (e.g. available energy and water, VPD) in addition to plant biological factors (Karam et al., 2005; Suyker and Verma, 2008, 2010). Suyker and Verma (2009) concluded that net radiation (Rn) over soybean explains $75 \%$ of the ET variability whereas during the growth phase, approximately $66 \%$ 

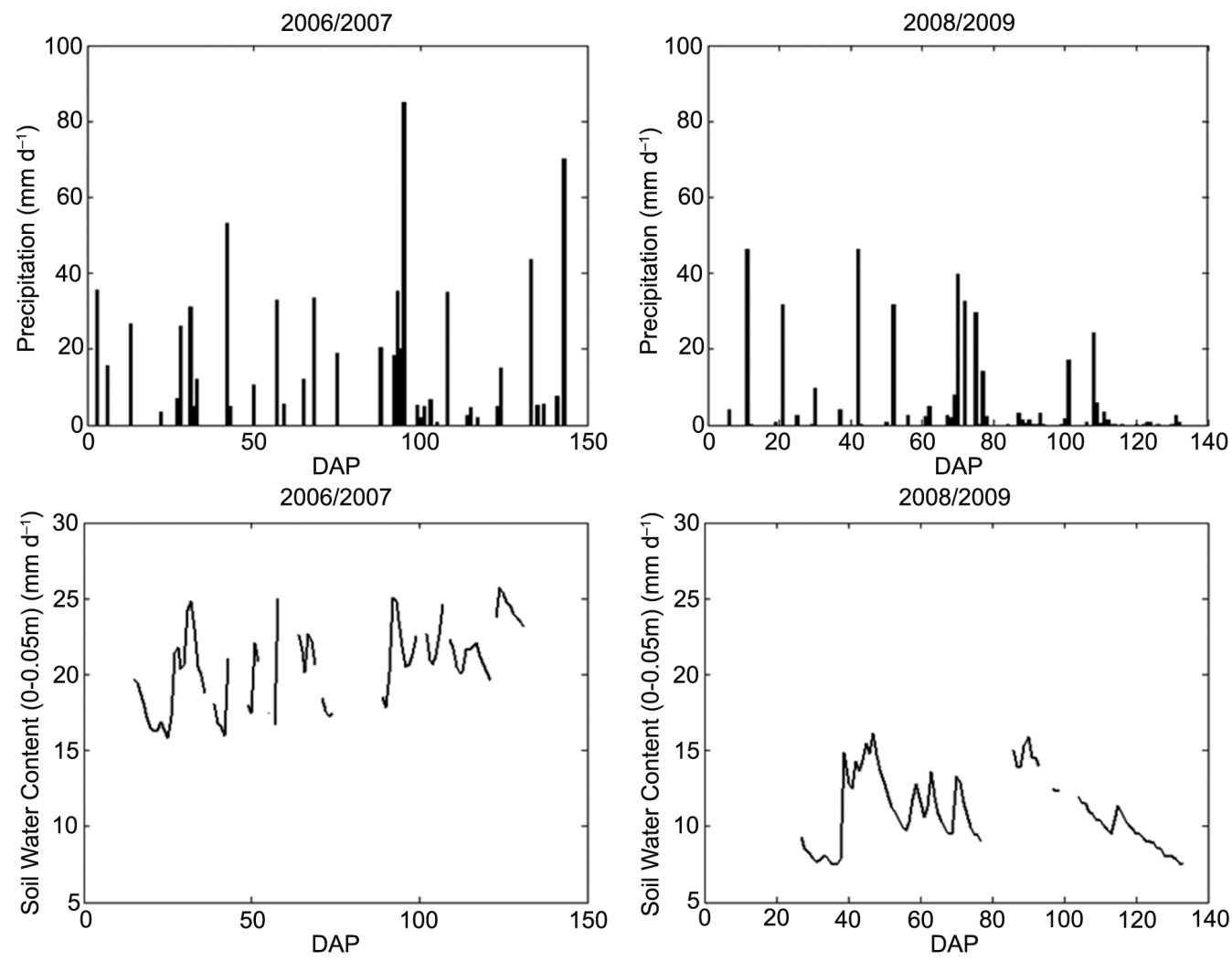

Figure 5 - Daily precipitation and soil moisture in the 0-0.05m depth for soybean growing seasons 2006/2007 and 2008/2009 under the No Till (NT) system. Timescale: Days After Plantation (DAP). The gaps in the soil water content plot mean missing data.
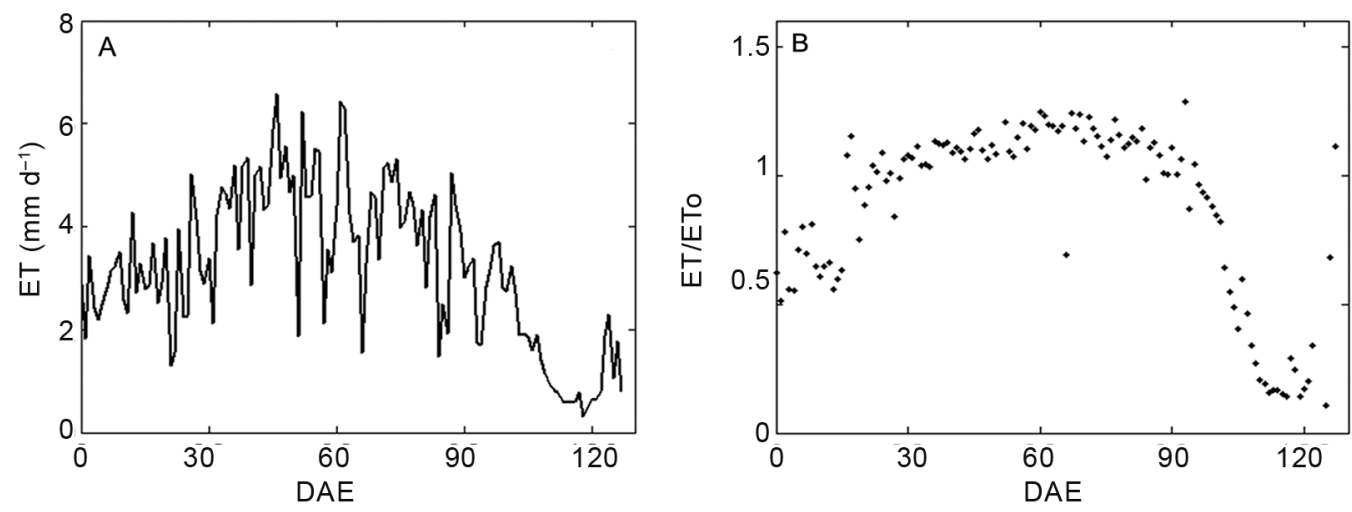

Figure 6 - (A) Seasonal distributions of evapotranspiration, and (B) variation of the daily crop coefficient Kc for the 2009/2010 soybean growing season.

of this variability is attributed to the number of days in which the leaf area index (LAI) was greater than $2.5 \mathrm{~m}^{2}$ $\mathrm{m}^{-2}$. Singer et al. (2010) showed that during the reproductive phase of soybean, transpiration accounts for 89 $\%$ to $96 \%$ of ET, indicating that the LAI strongly influences the ET rate

\section{Water balance}

Soil drainage was $168.4 \mathrm{~mm}$ and $108.9 \mathrm{~mm}$ during P1 for CT and NT respectively (Table 3). Greater runoff was observed in the CT plot, which is explained, in theory, by the enhancement effects of tillage on the infiltration process. The greatest differences in wa- 
Table 3 - Components of water balance for the 2009/2010 soybean growing season under No Till (NT) and Conventional Tillage (CT), in units of $\mathrm{mm}$ for different periods.

\begin{tabular}{lcccccc}
\hline Period & \multirow{2}{*}{ System } & Input & & Output & WB \\
& & P & ET & R & D & P-ET-R-D \\
\hline P1 - 19 Dec 2009 to 25 Apr 2010 & NT & 654.8 & $410.8^{*}$ & 12.1 & 108.9 & 123.0 \\
\hline \multirow{2}{*}{ P2 - 19 Dec 2009 to 19 Apr 2010 } & CT & 654.8 & $410.8^{*}$ & 20.6 & 168.4 & 55.0 \\
\hline
\end{tabular}

P - precipitation; ET - evapotranspiration; R - Surface runoff; D - drainage in the profile; WB - water balance calculated daily interval for the difference between the precipitate volume and the sum of the losses. ${ }^{*}$ We used the same ET for NT and CT.

ter balance between the systems were found in the drainage profile (redistribution process). Water losses through the bottom layer drainage for CT were approximately $50 \%$ higher than for NT because the soil profile in the area under tillage presented greater retention capacity when compared to the conventional system.

\section{Reference evapotranspiration (ETo) and crop coef- ficient $(\mathbf{K c})$}

ETo was higher than ET both at the beginning and at the end of the cycle. However, after the physiological maturity of the plant in addition to the high precipitation values, a slight increase in the rate of ET and reduction of ETo values was observed. The ratio of ET/ETo also known as the crop coefficient (Kc), (Allen et al., 1998) shows a different behavior during each stage of crop phenological development. The Kc factor is widely used for the design and optimization of agricultural practices. Figure $6 \mathrm{~b}$ shows the daily variation of $\mathrm{Kc}$ (ET/ETo) with values between 0.15 and 1.34. At the beginning of the period following planting (first 25 days) Kc ranged between 0.4 and 1.2, possibly because the culture is fully mature with the gradual increase in LAI. The increase in effective area due to an increase in LAI contributes to a steady increase in the ET/ETo ratio, and therefore the magnitude of Kc. With the increase in LAI values during the intermediate stages comes the decrease in soil exposure to direct solar radiation, in turn producing an increase in Kc values. During the final phases of the cycle (maturity period), there is a systematic decrease in Kc.

Table 4 shows the Kc values for soybean during the initial, middle and ending periods of the growing season, following the crop growth stages as recommended by Allen et al. (1998). The Kc calculation followed Suyker and Verma (2009) who estimated Kc for soybean under an NT system, in Nebraska, USA. The estimates obtained for this study (Table 4) show a similar pattern to those obtained by Suyker and Verma (2009) as with magnitudes in the order of those suggested by FAO (Allen et al., 1998). The highest values found in this study, when compared to Suyker and Verma's (2009) results, may be associated with differences in climatic regions, in addition to the high precipitation values that favor greater ET.
Table 4 - Crop coefficient $(\mathrm{Kc})$ values and $95 \%$ confidence intervals for specified periods of the 2009/2010 soybean growing season under No Till (NT) systems. The Kc data obtained by Allen et al. (1998) and Suyker and Verma (2009) for the 2004 soybean growing season are also included.

\begin{tabular}{lccc}
\hline Soybean & Initial Kc & Mid-season Kc & End Kc \\
\hline NT & $0.56 \pm 0.16$ & $1.07 \pm 0.15$ & $0.53 \pm 0.29$ \\
Allen et al. (1998) & & 1.15 & 0.5 \\
Suyker and Verma (2009) & $0.34 \pm 0.32$ & $0.95 \pm 0.41$ & $0.26 \pm 0.19$ \\
\hline
\end{tabular}

\section{Acknowledgements}

The authors wish to acknowledge the National Council for Scientific and Technological Development (CNPq - Brazil), the Coordination for the Improvement of Higher Education Personnel (CAPES - Brazil) and NASA for the project "Integrating NASA Earth Sciences Research results into Decision Support Systems for Agriculture and Water Management in South America" in the Program Announcement NNH08ZDA001N-DECISIONS for their financial support.

\section{References}

Allen, R.G.; Pereira, L.S.; Raes, D.; Smith, M. 1998. Crop Evapotranspiration: Guidelines for Computing Crop Water Requirements. FAO, Rome, Italy. (FAO Irrigation and Drainage Paper, 56).

Alberto, M.C.R.; Wassmann, R.; Hirano, T.; Miyata, A.; Hatano, R.; Kumar, A.; Padre, A.; Amante, M. 2011. Comparisons of energy balance and evapotranspiration between flooded and aerobic rice fields in the Philippines. Agricultural Water Management 98: 1417-1430.

Almaraz, J.J.; Zhou, X.; Mabood, F.; Madramootoo, C.; Rochette, P.; Ma, B.L.; Smith, D.L. 2009. Greenhouse gas fluxes associated with soybean production under two tillage systems in southwestern Quebec. Soil Tillage Research 104: 134-139.

Amado, T.J.C.; Bayer, C.; Conceição, P.C.; Spagnollo, E.; Campos, B.C.; Veiga, M. 2006. Potential of carbon accumulation in notill soils with intensive use and cover crops in southern Brazil. Journal of Environmental Quality 35: 1599-1607.

Aubinet, M.; Grelle, A.; Ibrom, A.; Rannik, U.; Moncrieff, J.; Foken, T.; Kowalski, A.S.; Martin, P.H.; Berbigier, P.; Bernhofer, C.; Clement, R.; Elbers, J.; Granier, A.; Grunwald, T.; Morgenstern, K.; Pilegaard, K.; Rebmann, C.; Snijders, 
W.; Valentini, R.; Vesala, T. 2000. Estimates of the annual net carbon and water exchange of forests: The EUROFLUX methodology. Advances in Ecological Research 30: 113-175.

Baldocchi, D.D.; Hicks, B.B.; Meyers, T.P. 1988. Measuring biosphere-atmosphere exchanges of biologically related gases with micrometeorological methods. Ecology 69: 13311340 .

Blevins, R.L.; Frye, W.W.; Baldwin, P.L.; Robertson, S.D. 1990. Tillage effects on sediment and soluble nutrient losses from a Maury silt loam soil. Journal of Environmental Quality 19: 683-686.

Boddey, R.M.; Jantalia, C.P.; Concepcion, P.; Zanatta, J.A.; Bayer, C.; Mielniczuk, J.; Dieckow, J.; Santos, H.P.; Denardin, J.E.; Aita, C.; Giacomini, S.J.; Alves, B.J.R.; Urquiaga, S. 2010. Carbon accumulation at depth in Ferralsols under zero-till subtropical agriculture. Global Change Biology 16: 784-795

Botta, G.F.; Becerra, T.A.; Bravo, X.L.; Tourn, M. 2010. Tillage and traffic effects (planters and tractors) on soil compaction and soybean (Glycine max L.) yields in Argentinean pampas. Soil Tillage Research 110: 167-174.

Chavez, L.F.; Amado, T.J.C.; Bayer, C.; La Scala, N.J.; Escobar, L.F.; Fiorin, J.E.; Campos, B.H.C. 2009. Carbon dioxide efflux in a rhodichapludox as affected by tillage systems in southern Brazil. Revista Brasileira de Ciência do Solo 33: 325-334.

De Vita, P.; Di Paolo, E.; Fecondo, G.; Di Fonzo, N.; Pisante, M. 2007. No-tillage and conventional tillage effects on durum wheat yield, grain quality and soil moisture content in southern Italy. Soil Tillage Research 92: 69-78.

Dogan, E.; Kirnak, H.; Copur, O. 2007. Deficit irrigations during soybean reprodutive stages and CROPGRO-soybean simulations under semi-arid climatic conditions. Field Crops Research 103: 154-159.

Egli, D.B.; Bruening, W.P. 2004. Water stress, photosynthesis, seed sucrose levels and seed growth in soybean. Journal of Agricultural Science 142: 1-8.

Engel, F.L.; Bertol, I.; Ritter, M.R.; Gonzalez, A.P.; Smith, P.B.J.; Vazquez, V.E. 2009. Soil erosion under simulated rainfall in relation to phenological stages of soybeans and tillage methods in Lages, SC, Brazil. Soil Tillage Research 103: 216-221.

Escobar, L.F.; Amado, T.J.C.; Bayer, C.; Chavez, L.F; Zanatta, J.A.; Fiorin, J.E. 2010. Postharvest nitrous oxide emissions from a subtropical Oxisol as influenced by summer crop residues and their management. Revista Brasileira de Ciência do Solo 34: 507-516.

Fabrizzi, K.P.; Rice, C.W.; Amado, T.J.C.; Fiorin, J.; Barbagelata, P.; Melchiori, R. 2009. Protection of soil organic C and $\mathrm{N}$ in temperate and tropical soils: effect of native and agroecosystems. Biogeochemistry 92: 129-143.

Falge, E.; Baldocchi, D.; Olson, R.; Anthoni, P.; Aubinet, M.; Bernhof, C.; Burba, G.; Ceulemans, R.; Clement, R.; Dolman, H.; Granier, A.; Gross, P.; Grunwald, T.; Hollinger, D.; Jensen, N.O.; Katul, G.; Keronen, P.; Kowalski, A.; Lai, C.T.; Law, B.E.; Meters, T.; Moncrieff, J.; Moors, E.; Munger, J.W.; Pilegaard, K.; Rannik, U.; Rebmann, C.; Suyker, A.; Tenhunen, J.; Tu, K.; Verma, S.; Vesala, T.; Wilson, K.; Wofsy, S. 2001. Gap filling strategies for long term energy flux data sets. Agricultural and Forest Meteorology 107: 71-77.
Gubiani, P.I.; Reinert, D.J.; Reichert, J.M.; Gelain, N.S.; Minella, J.P.G. 2010. Falling head permeameter and software to determine the hydraulic conductivity of saturated soil = Permeâmetro de carga decrescente associado a programa computacional para a determinação da condutividade hidráulica do solo saturado. Revista Brasileira de Ciência do Solo 34: 1-5 (in Portuguese).

Hernandez-Ramirez, G.; Hatfield, J.L.; Prueger, J.H.; Sauer, T.J. 2010. Energy balance and turbulent flux partitioning in a corn-soybean rotation in the Midwestern US. Theoretical and Applied Climatololy 100: 79-92.

Karam, F.R.; Masaad, R.; Sfeir, T.; Mounzer, O.; Rouphael, Y. 2005. Evapotranspiration and seed yield of field grown soybean under deficit irrigation conditions. Agricultural Water Management 75: 226-244

Kay, B.D.; Bygaart, A.J. van den. 2002. Conservation tillage and depth stratification of porosity and soil organic matter. Soil Tillage Research 66: 107-118.

Klein, V.A.; Libardi, P.L. 2002. Bulk density and pore size distribution of an oxisol under different use and management systems $=$ Densidade e distribuição do diâmetro dos poros de um Latossolo vermelho, sob diferentes sistemas de uso e manejo. Revista Brasileira de Ciência do Solo 26: 857-867 (in Portuguese).

Kucharik, C.J.; Twine, T.E. 2007. Residue, respiration, and residuals: evaluation of a dynamic model using eddy flux agroecossistem measurements and biometric data. Agricultural and Forest Meteorology 146: 134-158.

Leys, A.; Govers, G.; Gillijns, K.; Berckmoes, E.; Takken, I. 2010. Scale effects on runoff and erosion losses from arable land under conservation and conventional tillage: the role of residue cover. Journal of Hydrology 390: 143-154.

Lokupitiya, E.; Denning, S.; Paustian, K.; Baker, I.; Schaefer, K.; Verma, S.; Meyers, T.; Bernacchi, C.J.; Suyker, A.; Fischer, M. 2009. Incorporation of crop phenology in Simple Biosphere Model (SiBcrop) to improve land-atmosphere carbon exchanges from croplands. Biogeosciences 6: 969-986.

Matzenauer, R.; Barni, N.A.; Machado, F.A.; Da Rosa, F.S. 1998. Agroclimatic analysis of water availability for soybean crop in planalto médio of Rio Grande do Sul state, Brazil = Análise agroclimática das disponibilidades hídricas para a cultura da soja na região do Planalto Médio do Rio Grande do Sul. Revista Brasileira de Agrometeorologia 6: 263-275 (in Portuguese).

Mota, F.S.; Agendes, M.O.O.; Alves, E.G.P.; Signorini, E. 1996. Agroclimatological analysis of soybean irrigation needs in Rio Grande do Sul = Análise agroclimatológica da necessidade de irrigação da soja no Rio Grande do Sul. Revista Brasileira de Agrometeorologia 4: 133-138 (in Portuguese).

Périé, C.; Ouimet, R. 2008. Organic carbon, organic matter and bulk density relationships in boreal forest soils. Canadian Journal of Soil Science 88: 315-325.

Reichert, J.M.; Suzuki, L.E.A.S.; Reinert, D.J.; Horn, R.; Hakansson, I. 2009. Reference bulk density and critical degreeof-compactness for no-till crop production in subtropical highly weathered soils. Soil Tillage Research 102: 242-254.

Singer, J.; Heitman, J.; Hernandez-Ramirez, G.; Sauer, T.; Prueger, J.H.; Hatfield, J.L. 2010. Contrasting methods for estimating evapotranspiration in soybean. Agricultural Water Management 98: 157-163. 
Stipesevic, B.; Kladivko, E.J. 2005. Effects of winter wheat cover on soil moisture teams desiccation, temperature and early maize growth. Plant Soil Environment 51: 255-261.

Suyker, A.E.; Verma, S.B. 2008. Interannual water vapor and energy exchange in an irrigated maize-based agroecosystem. Agricultural and Forest Meteorology 148: 417-427.

Suyker, A.E.; Verma, S.B. 2009. Evapotranspiration of irrigated and rainfed maize-soybean cropping systems. Agricultural and Forest Meteorology 149: 443-452.

Suyker, A.E.; Verma, S.B. 2010. Coupling of carbon dioxide and water vapor exchanges of irrigated and rainfed maize-soybean cropping systems and water productivity. Agricultural and Forest Meteorology 150: 553-563.

Tan, C.S.; Drury, C.F.; Gaynor, J.D.; Welacky, T.W.; Reynolds, W.D. 2002. Effect of tillage and water table control on evapotranspiration, surface runoff, tile drainage soil and water content under maize on a clay loam soil. Agricultural Water Management 54: 173-188.

Tesar, M.B. 1984. Physiological Basis of Crop Growth and Development. American Society of Agronomy, Madison, WI, USA.
Tormena, C.A.; Barbosa, M.C.; Costa, A.C.S.; Gonçalves, A.C.A. 2002. Density, porosity and penetration resistance in cultivated Oxisol under different tillage systems. Scientia Horticulturae 59: 795-801.

Verkler, T.L.; Brye, K.R.; Ed, E.; Popp, J.H.; Amuri, N. 2008. Residue management and water delivery effects on seasonlong surface soil water dynamics in soybean. Soil Science 173: 444-455.

Webb, E.K.; Pearman, G.I.; Leuning, R. 1980. Correction of flux measurements for density effects due to heat and water vapor transfer. Quarterly Journal of Royal Meteorological Society 106: $85-100$

Wilson, K.B.; Goldstein, A.; Falge, E.; Aubinet, M.; Baldocchi, D. 2002. Energy balance closure at FLUXNET sites. Agricultural and Forest Meteorology 113: 223-243.

Wyngaard, J.C. 1990. Scalar fluxes in the planetary boundary layer-theory, modeling and measurement. Boundary Layer Meteorology 50: 49-75. 